\title{
PENGARUH PELAYANAN DAN FASILITAS TERHADAP KEPUASAN PASIEN DI RSUD LIMPUNG BATANG
}

\author{
Kharisma Nawang Sigit ${ }^{1)}$, Muhammad Syaqiq ${ }^{2)}$ \\ ${ }^{1,2}$ Fakultas Ekonomika dan Bisnis, Universitas Selamat Sri \\ Email: ${ }^{1}$ kharisma04337@gmail.com, ${ }^{2}$ syaqiq60@gmail.com
}

\begin{abstract}
This study aims to determine the influence of services and facilities on patient satisfaction in Limpung Batang Hospital. The poppulation in this study were all people who had been patients, both outpatients and inpatients. The sammpling technique in this study ussed the purposive sampling method, the researchers took samples that happened to be met at that time there were 50 patients who met the sample selection criteria. The data analysiss technique used in this ressearch is validity test, reliability test, normality test, multicollinearity test, heteroscedasticity test. The ressults showed that the service variable partially affected patient satisfaction with the value and the facility variable partially affected patient satisfaction. Service and facility variables simultaneously affect patient satisfaction in Limpung Batang Hospital.
\end{abstract}

Keywords: Services, facilities, patient satisfaction

\section{PENDAHULUAN}

Kesehatan merupakan hal yang terpenting dalam kehidupan. Pada era pandemi Covid-19 sekarang, sehat merupakan impian semua orang di belahan dunia. Sarana prasarana kesehatan di suatu daerah menjadi sangat penting adanya di era pandemi Covid-19. Menurut Asrul (2003:33) kesehatan dibutuhkan oleh manusia untuk menopang semua aktivitas hidupnya. Adanya sarana kesehatan seperti rumah sakit sangat dibutuhkan oleh masyarakat, setelah adanya jumlah rumah sakit yang memadai selanjutnya rumah sakit harus memiliki pelayanan dan fasilitas yang terbaik, guna memenuhi kebutuhan masyarakat yang membutuhkan pertolongan kesehatan. Pelayanan merupakan pondasi yang sangat bisa merubah pilihan masyarakat untuk menggunakan jasa kesehatan yang ada saat ini mulai dari jasa kesehatan modern sampai jasa kesehatan yang tradisional. Dalam era pandemi Covid-19 saat ini menyebabkan manusia diharuskan memilih rumah sakit yang pelayanannya terbaik, cepat, dan punya fasilitas yang lengkap.

Kabupaten Batang memiliki dua rumah sakit daerah, yakni RSUD Batang dan RSUD Limpung. Masyarakat akan menuntut pelayanan serta fasilitas yang lengkap sesuai dengan kebutuhan terutama masalah sarana penunjang kesehatan. Menyadari hal tersebut, pentingnya sarana kesehatan khususnya dalam hal pelayanan dan fasilitas di rumah sakit, semua rumah sakit seyogyanya disertai dengan kebutuhan masyarakat dan dengan pelayanan aman, ramah, murah, berkualitas, disertai peralatan yang modern dan lengkap.

Tjiptono (2002:6) menerangkan pelayanan adalah aktivitas, manfaat, atau kepuasan yang ditawarkan untuk dijual. Macam-macam jenis dan bentuk pelayanan yang disajikan oleh rumah sakit turut mempengaruhi kepuasan pasien, serta akan menimbulkan dampak terhadap rumah sakit tersebut. Dampak yang ditimbulkan antara lain pasien akan terus menggunakan jasa dari rumah sakit tersebut atau pindah menuju rumah sakit lainnya bahkan masyarakat akan memilih ke rumah sakit swasta daripada ke rumah sakit pemerintah, yang tentunya akan memberi pelayanan lebih baik. Beberapa hal yang perlu diberikan, di antaranya adalah fasilitas dan pelayanan yang diberikan. Tjiptono (2001:184) menerangkan bahwa fasilitas merupakan sumber daya fisik yang harus ada sebelum suatu jasa dapat ditawarkan kepada pasien. Beberapa fasilitas dari rumah sakit, misal kursi, AC yang dingin, WC, ruang perawatan yang banyak, peralatan 
kesehatan yang lengkap dan modern, serta dokter spesialis yang lengkap. Menurut Tjiptono (2005:210) kepuasan yang dirasakan seorang yang salah mengalami suatu hasil yang sesuai harapannya. Jadi kepuasan adalah fungsi menurut taraf keinginan yang dinikmati menurut output aktivitas. Jika suatu output aktivitas melebihi keinginan seorang, orang tadi akan dikatakan mengalami taraf kepuasan yang tinggi (fully satisfled). Jika output kerja itu sama menggunakan yang diharapkan, seorang dikatakan puas (satisfied). Tapi jika output tadi jauh di bawah keinginan, seseorang akan merasa tidak puas. Menurut Wardani (2006:34) menyebutkan faktor-faktor yang mempengaruhi kepuasan konsumen, yaitu: 1) Karakteristik produk, produk ini adalah kepemilikan rumah sakit yang bersifat fisik di antaranya gedung dan dekorasi; 2) Harga; 3) Pelayanan; 4) Lokasi; 5) Fasilitas; 6) Image; 7) Desain visual; 8) Suasana; 9; Komunikasi; dan 10) Dibutuhkan pengguna jasa rumah sakit. Berdasarkan uraian tersebut, didapat kesimpulan bahwa pelayanan dan fasilitas berpengaruh terhadap kepuasan pasien. Dari hal tersebut di atas, penulis tertarik untuk melakukan penelitian dengan judul "Pengaruh Pelayanan dan Fasilitas terhadap Kepuasan Pasien di RSUD Limpung Batang".

\section{METODE PENELITIAN}

Penelitian ini menggunakan jenis penelitian studi kasus pada semua pasien di RSUD Limpung Batang. Subyek yang dipergunakan adalah semua pasien, baik rawat jalan ataupun pasien inap di RSUD Limpung Batang. Obyek yang digunakan adalah persepsi pasien terhadap pelayanan, fasilitas dan kepuasan pasien. Penelitian dilakukan di RSUD Limpung Batang.

Teknik penentuan sampel pada penelitian ini dengan metode penentuan sampel purposive sampling, peneliti mengambil sampel yang secara kebetulan ditemui saat itu ada 50 pasien yang memenuhi kriteria pemilihan sampel. Teknik pengolahan data yang digunakan pada penelitian ini adalah uji validitas, uji reliabilitas, uji normalitas, uji multikolinieritas, dan uji heteroskedastisitas. Variabel bebas dalam penelitian ini adalah pelayanan dan fasilitas, sedangkan variabel terikat pada penelitian ini adalah kepuasan pasien.

Rumusan masalah pada penelitian ini adalah bagaimana pelayanan berpengaruh terhadap kepuasan pasien, bagaimana fasilitas berpengaruh terhadap kepuasan pasien, serta bagaimana pelayanan dan fasilitas secara bersama-sama berpengaruh terhadap kepuasan pasien.

Adapun menurut Parasuraman dalam Lupiyoadi (2013:148) indikator pelayanan yaitu: 1) Pelatihan; 2) Daya tanggap; 3) Kehandalan; 4) Jaminan; dan 5) Empati. Menurut Tjiptono (2014:46-48) indikator fasilitas, yaitu: 1) Pertimbangan/perencanaan spasial; 2) Perencanaan ruang; 3) Perlengkapan/ perabotan; 4) Tata cahaya; 5) Warna; dan 6) Unsur pendukung. Menurut Tjiptono (2004:62) indikator kepuasan yaitu: 1) Penyedian layanan baik; 2) Karyawan cepat dalam menyelesaikan pekerjaan; 3) Karyawan bisa mengerti kemauan; 4) Mendiagnosis hal yang harus di lakukan dengan cepat; 5) Karyawan memberi perhatian yang baik terhadap keluhan. Penelitian ini menggunakan teknik pengambilan data dengan wawancara dan membagikan kuesioner pertanyaan ke pasien di RSUD Limpung Batang.

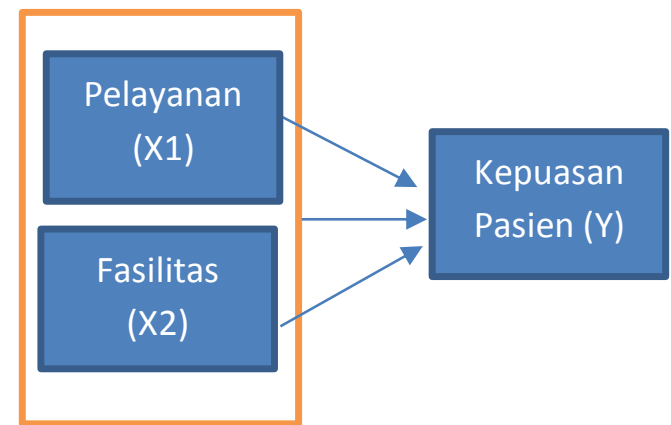

Gambar 1 Hubungan Pelayanan dan Fasilitas terhadap Kepuasan Pasien

\section{HASIL DAN PEMBAHASAN}

3.1. Hasil Pengujian Validitas

Digunakan untuk mengukur sejauh mana alat pengukur mengukur apa yang diukur, dengan rumus :

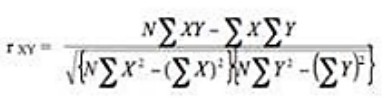

$$
\begin{aligned}
& \text { Keterangan: } \\
& \text { IXY }=\text { Kosfisicnsi korelasi } \\
& \text { X }=\text { Skoc pertanyaan tinp nomor } \\
& \mathrm{Y} \quad=\text { Jumlah skor total pertanyaan } \\
& \text { N = Jumlah responden }
\end{aligned}
$$


Jika $\mathrm{r}$ hitung (pernyataan dilihat di kolom Correcteed Item - Total Correlation) $>\mathrm{r}$ tabel dan nilai $\mathrm{r}+$ maka valid. Berdasarkan analisis yang sudah diolah data, diperoleh hasil pengujian validitas yang dapat dilihat dalam tabel ini:

Tabel 1 Hasil Pengujian Validitas dan Reliabilitas

\begin{tabular}{llll} 
Variabel & Pertanyaan & $\begin{array}{c}\text { Koefisien } \\
\text { Alpha }\end{array}$ & $\begin{array}{c}\text { Corrected Item- } \\
\text { Total } \\
\text { Correlation }\end{array}$ \\
\hline \multirow{5}{*}{ Pelayanan } & Q1 & & 0,354 \\
& Q2 & & 0,312 \\
& Q3 & 0,754 & 0,362 \\
& Q4 & & 0,341 \\
& Q5 & & 0,364 \\
\hline \multirow{5}{*}{ Faasilitas } & Q6 & & 0,313 \\
& Q7 & & 0,321 \\
& Q8 & 0,64 & 0,32 \\
& Q9 & & 0,31 \\
Kepuasan & Q10 & & 0,321 \\
\hline \multirow{5}{*}{ Pasien } & Q11 & & 0,592 \\
& Q12 & 0,621 & 0,578 \\
& Q14 & & 0,57 \\
\hline
\end{tabular}

Berdasarkan pengujian reliabilitas di atas menyatakan hasil yang diperoleh reliabel. Corrected ittem-total correlattion menunjukkan koefisien korelasi indikator menghasilkan nilai seluruh indikator masing-masing variabel ada di atas 0,30. Bahwa instrumen pengukuran yang dipakai pada penelitian sah atau valid. Hasil pengujian reliabilitas dan validitas menunjukkan instrumen pengukuran yang dipakai pada penelitian ini reliabel atau valid.

\subsection{Pengujian Normalitas}

Dipakai untuk menentukan apakah sebuah model terdistribusi normal atau tidak dengan cara lihat di histogram residual apakah punya model layaknya 'lonceng' atau tidak. Cara tersebut bisa berakibat fatal apabila dalam mengambil keputusan data yang terdistribusi normal ataukah tidak hanya berpatokan dalam melihat pada hasil gambarnya. Adapun hasilnya dari pengujian ini dapat dilihat dalam tabel berikut:

Tabel 2 Hasil Uji Normalitas

\begin{tabular}{|c|c|c|c|}
\hline Variabel & $\begin{array}{l}\text { Asymp.Sig } \\
\text { (2-tailed) }\end{array}$ & $\alpha=5 \%$ & $\begin{array}{c}\text { Berdistribusi } \\
\text { Normal atau Tidak }\end{array}$ \\
\hline Pelayanan & 0,587 & $\begin{array}{l}\text { Lebih } \\
\text { Besar }\end{array}$ & $\begin{array}{c}\text { Berdistribusi } \\
\text { Normal }\end{array}$ \\
\hline Fasilitas & 0,384 & $\begin{array}{l}\text { Lebih } \\
\text { Besar }\end{array}$ & $\begin{array}{c}\text { Berdistribusi } \\
\text { Normal }\end{array}$ \\
\hline $\begin{array}{c}\text { Kepuasan } \\
\text { Pasien }\end{array}$ & 0,032 & $\begin{array}{l}\text { Lebih } \\
\text { Besar }\end{array}$ & $\begin{array}{l}\text { Berdistribusi } \\
\text { Normal }\end{array}$ \\
\hline
\end{tabular}

Berdasarkan hasil uji normalitas kolmogrov smirnov menghasilkan Asympp. Sig. (2-tailed $)=0,32$ dan signifikan. Karena hasilnya harus $>\alpha=0,05$, maka angka pada tiap variabel terdistribusi normal serta bisa dipakai pada pengujian ke depannya.

\subsection{Uji Multikolinieritas}

Untuk menguji model regresi ditemukan kolerasi antar variabel bebas atau tidak. Uji ini bisa diketahui berdasarkan nilai tolerance serta Variance Inflation Factor (VIF), serta bisa dilihat pada tabel di bawah:

\begin{tabular}{|c|c|c|}
\hline \multicolumn{3}{|c|}{ Tabel 3 Pengujian Multikolioneritas } \\
\hline Variabel & Tolerance & VIF \\
\hline Pelayanan & .903 & 1.120 \\
\hline Fasilitas & .892 & 1.122 \\
\hline Kepuasan Pasien & .812 & 1.234 \\
\hline
\end{tabular}

Tabel 3.3 menunjukan tidak adanya variabel yang mempunyai $\mathrm{VIF} \geq 10$ dan toleran $\geq 0,10=$ tingkat kolonieritas 0,95 ini berarti tidak adanya korelasi antara variabel bebas atau tidak adanya multikolinieritas pada semua variabel.

\subsection{Uji Heterokedastisitas}

Dipakai untuk menguji model regresi apakah terjadi ketidaksamaan varian residual satu dengan lainnya. Apabila varian residual satu ke yang lain tetap maka homoskedastisitas dan apabila beda disebut heteroskedastisitas. Model regresi yang baik adalah model dengan homoskedastisitas atau tidak terjadi heteroskedastisitas. Lebih jelasnya bisa lihat di tabel ini:

\begin{tabular}{ccc}
\multicolumn{3}{c}{ Tabel 4 Pengujian Heterokedastisistas } \\
Variabel & T & Sig \\
\hline Pelayanan & .732 & .462 \\
\hline Fasilitas & 1.435 & .153 \\
\hline Kepuasan Pasien & .233 & .733 \\
\hline
\end{tabular}

Hasil pengujian menunjukkan bahwa seluruh variabel yang tidak terikat mempunyai $\mathrm{T}$ hitung kurang dari $\mathrm{T}$ tabel yang berarti tidak signifikan dan bisa dikatakan seluruh variabel yang tidak terikat tidak terkena heterokedastissitas. 
Tabel 5 Hasil Uji Hipotesis

Uji Koefisien DeterminanR2

Model Summaryb

\begin{tabular}{|c|c|c|c|c|}
\hline Model & $\mathrm{R}$ & R Square & $\begin{array}{l}\text { Adjusted } \\
\text { R } \\
\text { Square }\end{array}$ & $\begin{array}{l}\text { Std. Error of } \\
\text { the } \\
\text { Estimate }\end{array}$ \\
\hline 1 &, 613 & .376 &, 362 & 1,91113 \\
\hline
\end{tabular}

a. Predicitors: (Constant), Pelayanan, Fasilitas

b. Dependent Variable: Kepuasan

Uji Statistik t

\begin{tabular}{|c|c|c|c|c|c|}
\hline \multirow{2}{*}{ Model } & \multicolumn{2}{|c|}{$\begin{array}{l}\text { Unstandardized } \\
\text { Coefficients }\end{array}$} & \multirow{2}{*}{$\begin{array}{c}\text { Standardiz } \\
\text { ed } \\
\begin{array}{c}\text { Coefficient } \\
s\end{array} \\
\text { Beta }\end{array}$} & \multirow{2}{*}{$t$} & \multirow{2}{*}{ Sig. } \\
\hline & B & Std. Error & & & \\
\hline (Constant) & 9,233 & 2,275 & & 4,059 & .000 \\
\hline Pelayanan & 248 &, 078 & 279 & 3,165 &, 002 \\
\hline Fasilitas & ,401 &, 077 & ,457 & 5,188 &, 000 \\
\hline
\end{tabular}

Uji Statistik F

ANOVA $^{\text {a }}$

\begin{tabular}{|ll|c|c|c|c|}
\hline \multicolumn{1}{|c|}{ Model } & $\begin{array}{c}\text { Sum of } \\
\text { Squares }\end{array}$ & $\begin{array}{c}\text { Mean } \\
\text { Square }\end{array}$ & F & Sig. \\
\hline 1 & Regression & 202,463 & 101,231 & 27,716 & $.000^{\mathrm{b}}$ \\
& Residual & 336,022 & 3,652 & & \\
Total & 538,484 & & & \\
\hline
\end{tabular}

a. Dependent Variable: Kepuasan

b. Predictors: (Constant), Pelayanan

\section{KESIMPULAN}

Adapun tujuannya dilakukan penelitian ini guna mengetahui bagaimana pelayanan berpengaruh pada kepuasan pasien di RSUD Limpung Batang, bagaimana fasilitas berpengaruh pada kepuasan pasien di RSUD Limpung Batang, serta bagaimana pelayanan serta fasilitas bersama-sama mempunyai pengaruh pada kepuasann pasien di RSUD Limpung Batang. Berdasarkan pengumpulan data yang dilakukan melalui pembagian kuesioner dan wawancara, lalu dilakukan olah data melalui pengujian, maka diperoleh hasil ;

a. Variabel pelayanan memiliki pengaruh yang positif pada kepuasan pasien di RSUD Limpung Batang.

b. Variabel fasilitas berpengaruh positif pada kepuasan pasien di RSUD Limpung Batang

c. Variabel pelayanan serta variabel fasilitas bersama-sama mempunyai pengaruh yang positif pada kepuasan pasien di RSUD Limpung Batang.

\section{REFERENSI}

Asrul, Aswar. (2003). Menjaga Mutu Pelayanan Kesehatan. Sinar Harapan. Jakarta.

Batang Kabupaten. (2021). Rumah Sakit Umum Daerah Limpung. Di akses pada 8 Juli 2021, dari https://rsudlimpung.batangkab.go.id/

Lupiyoadi, Rambat. 2006. Manajemen Pemasaran Jasa, Edisi Kedua. Jakarta : Penerbit Salemba Empat.

Tjiptono, Fandiy dan Geregorius Chandra. 2011. Service, Quality \& Satisfication, Edisi Kedua, Yogyakarta : Penerbit ANDI Yogyakarta.

Wardani. (2006). Penyusunan Indikator Kepuasan Pasien Rawat Inap Rumah Sakit. di Provinsi Jawa Tengah. Jurnal Manajemen Pelayanan Kesehatan Volume 09 Nomor 4. Desember 2006. Jakarta. 